\author{
Marcin ADAMCZYK \\ University of Wrocław, Faculty of Social Science, Poland
}

\title{
The Islamic State as a Potential Threat to the National Security of the People's Republic of China
}

\author{
Potencjalne zagrożenie dla bezpieczeństwa narodowego \\ Chińskiej Republiki Ludowej ze strony Państwa Islamskiego
}

\section{- Abstrakt •}

Niniejsza praca poświęcona jest analizie zagrożenia, jakie nieść może za sobą działalność Państwa Islamskiego dla bezpieczeństwa narodowego Chin. W artykule pokrótce opisana została historia powstania ISIS i sposób funkcjonowania tej organizacji. Autor ponadto analizuje zagadnienia klasyfikacji Daesh jako specyficznego podmiotu stosunków międzynarodowych. Natomiast w dalszej części poruszona została kwestia rekrutacji zagranicznych bojowników w szeregi PI. Jak się wydaje, to właśnie terroryści pochodzący z chińskiego Sinkiangu, którzy mają za sobą okres walk w szeregach ISIS, mogą stanowić główne zagrożenie dla bezpieczeństwa wewnętrznego i zagranicznych interesów ChRL. Problemy badawcze, na które w niniejszej pracy znaleźć można odpowiedzi, to pytania o nature zagrożenia, jakie może stanowić Państwo Islamskie dla chińskiego bezpieczeństwa narodowego. Do badań wykorzystana zostanie metoda historyczna oraz, w mniejszym stopniu, metoda analogii i ujęcie ilościowe.

\section{- Abstract •}

This paper is devoted to the analysis of the threat that the activities of the Islamic State may pose to the national security of China. The article briefly describes the history of the establishment of ISIS and the functioning of the organization. The author also analyses the issues of classification of Daesh as a specific subject of international relations. In the next part of the article, the problem of recruitment of foreign fighters into the ranks of IS is discussed. It seems that it is the Chinese Xinjiang terrorists, who have had a time of fighting in the ranks of ISIS, that may pose a major threat to internal security and foreign interests of the PRC. The research problems for which answers can be found in this work are questions about the nature of the possible threat that the Islamic State may pose to the PRC. Is this threat still relevant after the inevitable destruction of the IS in Syria and Iraq in 2019? The present research has been carried out using the analysis and synthesis of secondary research material in the form of scientific studies and source texts. The research will use the historical method and, to a lesser extent, the analogy and quantitative approach. 
Słowa kluczowe: Państwo Islamskie; Chiny; Ujgurzy; terroryzm
Keywords: Islamic State; China; Uyghurs; terrorism

\section{Introduction to the Research}

The Islamic State (IS, ISIS, Daesh) has suffered numerous defeats on the Syrian and Iraqi fronts over the past two years (Repetowicz, 2017a, 2017b, 2017c). They resulted not only in the loss of practically the entire territory conquered so far, but also in a significant drop in income and recruitment potential (Wojciechowski, 2016, p. 144). It seems, however, that the idea that was behind the creation of Daesh is probably still one of the most important threats to global security (Chatterjee, 2018; Durac, 2018). It is worth noting in this context the last year declaration of the US Secretary of Defense, James Mattis, on the change of the strategy to combat it. According to General Mattis, the allied forces are to focus on the complete annihilation of the PI, thus preventing foreign fighters from returning to their countries of origin after the end of the fighting (Face the Nation, 2017). The statement of the Secretary of Defense undoubtedly indicates the importance that the United States attaches to the final elimination of the threat from Daesh, which, as a result of the disasters suffered in the Syrian-Iraqi border region, has transferred part of its operations to Africa, Asia and Europe (RT, 2017a, 2017b, 2017c, 2017d; Worley, 2017; Al-Jazeera, 2017; Europol, 2016). One of the potential targets (or even one of its new base of operation) of the former Islamic State militians may also be China ${ }^{1}$. Is worth mentioning that PRC, as author's earlier research has shown, has been struggling with the problem of Islamic terrorism in the western Xinjiang province for years (Adamczyk, 2016, pp. 13-24). It should be emphasized that some of the Uyghurs living in this region have formally joined the ranks of ISIS, so after the defeat of the organizations they can return to the People's Republic of China to continue their fight (terrorist activity) there or in neighbouring countries - e.g., Chinese embassy in Bishkek in Kyrgyzstan was already the target of an attack by Uighur terrorists in 2016 (Hope, 2018; Dzyubenko, 2016). It should be noted that within the framework of this article, the Islamic State will be treated broadly as the idea of an Islamic caliphate built through acts of terrorism. This assumption is supported not only by the fact that ISIS in its effectiveness and brutality is far ahead of al-Qaeda, but also the very idea of a caliphate will surely survive the destruction of the organization in its cradle in the Syrian-Iraqi border region. The same undoubtedly applies to the structures

\footnotetext{
1 What they already announced at the beginning of 2017 (Gramer, 2017; Botobekov, 2017).
} 
and resources of an organization which, more than once in its history (as will be mentioned in the first part of this work), has shown its flexibility.

The research problems for which answers can be found in this work are questions about the nature of the possible threat that an Islamic State may pose to the PRC. Is this threat still relevant after the inevitable destruction of the IS in Syria and Iraq in 2019? The research will use the historical method and, to a lesser extent, the analogy and quantitative approach. The present research has been carried out using the analysis and synthesis of secondary research material in the form of scientific studies and source texts. The author used numerous scientific research (including the results of his own, previously conducted research), as well as electronic sources in the form of reports and analyses of leading domestic and foreign think tanks and information agencies, films and other propaganda materials produced by Daesh available on-line. Editorial requirements encourage the author to briefly describe selected threads, and appropriate links will enable the reader to become acquainted with wider material on a given topic.

\section{The Islamic State - the History of its Rising}

Although sometimes controversial, there seems to be a consensus among researchers that the origins of ISIS can be traced back to the "Group of Monotheism and Jihad" (Arabic: Jama'at al-Tawhid wal-Jihad), a group established in Jordan in 1999 by Abu Musaba az-Zarkawi (Azoulay, 2016, p. 157; Grabowski, 2016, p. 71; Roman, 2016, p. 69). After the American invasion of Iraq in 2003, az-Zarkawi moved his operations there, and in the following year he took the oath of allegiance to Usama ibn Ladin and transformed his organization into "Organization of Jihad's Base in Mesopotamia" (Arabic: Tanzim Qaidat al-Jihad $f i$ Bilad al-Rafidayn; also known as "Al-Qaeda in Iraq"). As a result of his unprecedented brutality, at the end of his life, this Jordanian terrorist was sought not only by US forces, but also by various Iraqi groups. Eventually, in 2006, he was killed in American air raid, and his successors were Abu Ayyub al-Masri and Abu Omar al-Baghdadi, who in the same year (or in 2007) transformed the organization into an "Islamic State in Iraq" (ISI; Arabic: Dawlat al-Irāq al-'Islämiyyah) and directed it to their death from Iraqi and American soldiers in $2010^{2}$. Abu Bakr al-Baghda$\mathrm{di}$, who intensified terrorist operations in Iraq, also undertook a kind of reform of

2 Whereas there are indications that Abu Ayyub al-Masri and Abu Omar al-Baghdadi are the same person (Roggio, 2008). 
the group, including accepting former high rank commanders of Saddam Hussein's army in its ranks (Azoulay, 2016, pp. 157, 161; Grabowski, 2016, pp. 71-72; Roman, 2016, p. 70; Szafarz, 2016, pp. 47-48; Waśko-Owsiejczuk, 2017, pp. 10, 19). Meanwhile, the situation in Iraq and its immediate surroundings has changed significantly. Another term of office of Iraqi Prime Minister Nuri al-Maliki's government caused an eruption of dissatisfaction in the country (mainly among Sunnis) and exacerbated the already existing chaos. Moreover, in 2011 the United States, in accordance with the American-Iraqi agreement, withdrew its troops from the country (Roman, 2016, p. 70; Waśko-Owsiejczuk, 2017, p. 24; Karczewski, 2015, pp. 201-204). At the same time, still in 2010 there were mass protests in most of the Maghreb and Mashreq countries (the so-called "Arab Spring"), and as a result, among other things, the civil war in Syria has begun (Dzisiów-Szuszczykiewicz, 2011, pp. 41-55; Jankowski, 2011, pp. 57-67; Kumelska, 2012, pp. 391-408; Roman, 2016, p. 70; Azoulay, 2016, p. 161). Al-Baghdadi took advantage of the favourable circumstances and extended the ISIS' area of activity to the territory of a neighbouring country and in early 2013 announced the merger with the al-Nusra Front (the Syrian branch of al-Qaeda) and the creation of a new organization called the "Islamic State of Iraq and Syria/Levant" (ISIS/ISIL; Arabic: ad-Dawlah al-Islämiyah fì 'l-Irāq wa-sh-Shäm). The new leader of al-Qaeda Ajman az-Zawahiri ${ }^{3}$, like the leader of the Front Abu Muhammad al-Jawlani, strongly opposed Abu Bakr al-Baghdadi's initiative and called on him to leave Syria - and when he refused, in February 2014, they broke off links with ISIS. Al-Baghdadi's organization managed to obtain significant territorial acquisitions in Syria and Iraq during this period, led by the third largest Iraqi city - Mosul, which was captured by ISIS in June 2014 (see more: Lewis \& Ali, 2014). At its height, Abu Bakr al-Baghdadi proclaimed the creation of the Islamic State on June 29, 2014, with the capital in the Syrian Ar-Rakka, and proclaimed himself a caliph (Surdyk, 2014, p. 45; Azoulay, 2016, pp. 159, 161-162; Grabowski, 2016, p. 74; Szafarz, 2016, pp. 48-49; Karczewski, 2015, p. 205).

\section{What is the Islamic State in the First Place?}

Ewelina Waśko-Owsiejczuk emphasizes that the answer to the above question is not obvious at all. What is more, the question itself is justified in fact that since

${ }^{3}$ Usama ibn Ladin was killed in the famous operation "Neptune Spear" of US Navy SEALs in May 2011 in Pakistan. 
the Second World War, no armed organization has controlled such a vast territory (equal to about $2 / 3$ of Poland's area) and has not obtained regular and significant income (IS's assets alone were estimated not long ago at 2-4 billion dollars). Initially financed by the Gulf countries, together with the successive conquests of ISIS, it became somewhat independent from external money. In addition to significant gold and cash resources from Iraqi and Syrian banks, the Islamic State has acquired numerous oil wells (until recently $60 \%$ of total oil production in Syria came from areas under its control), gas wells and phosphate mines, as well as cultivated fields ( $40 \%$ of grain production in Syria) and museums full of valuable works of art. ISIS sells all this (as well as people, organs for transplantation, or drugs - see more: Dziennik.pl, 2014; Sputnik, 2014) on the black market and, according to various estimates, earns between 1 million and even 3 million dollars a day. In addition, various taxes and other benefits (including electricity and water charges) have been imposed on people living in conquered territories. Most probably an important item in the budget of this organization are also kidnappings (mainly foreign citizens) for ransom, looting or transfers from foreign sympathizers (Azoulay, 2016, p. 159; Grabowski, 2016, p. 73; Szafarz, 2016, pp. 49-50; Wojciechowski, 2016, p. 149; Waśko-Owsiejczuk, 2017, p. 11).

Although Daesh clearly declares itself to be a state entity, in the realm of politics, as well as in the world of science, this position is widely questioned. Wojciech Grabowski classifies the Islamic State in the category of violent non-state actors (Grabowski, 2016, p. 73). He also points out that "IS is more than just an Islamic movement (like al-Qaeda) that seeks to unite Muslims. IS wants to build a socio-cultural community of people who will find their home in the territories conquered by the organization" (Grabowski, 2016, p. 70). Undoubtedly, ISIS is Islamic not only by name and its connection with the Sunni branch of this religion is very strong (see more: VICE News, 2014a, 2014b). As Barbara Pasamonik emphasizes, although there are voices of politicians and scientists questioning IS's "Islamicism", in her opinion it is "a collective enchantment of reality" (Pasamonik, 2016, p. 17). Maciej Karczewski also points out that the appointment of the caliphate is an attempt to "(...) create a real state, understood as a political territorial unit equipped with central power" (Karczewski, 2015, p. 206). However, as Sebastian Wojciechowski stresses, although ISIS has the attributes of statehood in the form of population, territory and power, in order for it to be considered a state it should be able to enter into international relations and fulfill the condition of external sovereignty (Wojciechowski, 2016, p. 143). Grabowski develops this issue in an interesting way, pointing out that although IS has the above mentioned 3 out of 4 characteristics of a state, at least two of them are implemented in at least a dispu- 
table way. Although ISIS does indeed control a certain population living in the conquered territories, the right to self-determination is not exercised (the extreme Islamic form of the state has been imposed on it), very few of them have received documents proving the "citizenship" of the new caliphate, and their loyalty to the new authorities seems to be limited. With regard to territory, he points out that not only has it been acquired in violation of international law, but it is also currently under regular attacks from a broad international coalition, so it is impossible to determine how permanent the borders of the caliphate are. On the other hand, the issue of effective control over the occupied territory and its population (although it should be borne in mind that this is a totalitarian form of government based on a fundamentalist interpretation of the Quran) and IS's inability to enter into international relations with actors other than itself (e.g., Boko Haram in Nigeria) raises no questions (Grabowski, 2016, pp. 75-83). Wojciechowski therefore concludes that: "The Islamic State is a new and modern form of terrorist activity. It goes beyond the classic understanding of a terrorist organization, controlling supranational territory or having extensive structures in place to achieve its objectives. The Islamic State is a hybrid terrorist structure that combines the characteristics attributed to: a terrorist organization, a criminal group, a state, a terrorist network or armed formation" (Wojciechowski, 2016, p. 144). It seems that this is a rather accurate approach to the essence of ISIS, and at the same time an interesting answer to the question posed earlier in the title of the chapter. It is worth mentioning here that both Wojciech Grabowski and Arkadiusz Machniak classify Daesh as a quasi- or para-state (Grabowski, 2016, p. 70; Machniak, 2016, p. 136). The concise statement of the American Department of State that ISIS is more than just an "ordinary" terrorist organization - an army that aims to have its own state also sounds very interesting and accurate (McCoy, 2014). We can say beyond any doubt that the Islamic State carries out terrorist activities - it uses violence on the territory of the opponent (assassinations) and strives to "speed up" the war, i.e., to maximize bloodshed in the shortest possible time (Münkler, 2004, pp. 42-43).

\section{Foreign Fighters in the Ranks of the ISIS}

Although probably in the common consciousness of a typical Westerner the Islamic State is slowly becoming only some kind of an unpleasant memory, it is hard to say that it no longer constitutes a significant threat to global security. It is worth recalling that a year ago, practically every few days we witnessed further terrorist attacks committed by ISIS members (or only supporters) in Europe and 
around the world ${ }^{4}$. Many analysts say that after the inevitable failure in 2019 Daesh will not disappear, but will only for some time go underground (Dubin, 2018; Byman, 2018). Undoubtedly, even if the caliphate collapses, the idea of an Islamic state built on unprecedented brutality towards all disbelievers will survive. Also foreign fighters who left their countries and went to the Middle East to join the fight on the side of IS may constitute a considerable danger. With IS defeat in Syria and Iraq, most of them will probably try to avoid death at the hands of coalition soldiers and will face the dilemma of whether to continue the fight in the "homeland" or go to countries where relatively strong Daesh structures were created earlier. The aforementioned Secretary James Mattis warned against such a threat, as well as Europol in the report referred to in the introduction. Arkadiusz Machniak emphasizes that the Islamic State enjoyed unexpectedly large support among Muslims in the world, which resulted in a mass influx of recruits - by the end of 2015, almost 5,000 potential terrorists/fighters left Europe alone to the Middle East; over 11,000 from Africa and other Middle Eastern countries in total; 3,500 from former ex-Soviet states; from Asia and Australia over 1,000; from North America about 200 (Machniak, 2016, pp. 128, 134-135; Ajili, 2016, p. 51; see more: Fijałkowski \& Jarząbek, 2016, pp. 63-76; Dyner, Legieć, \& Rękawek, 2015, pp. 1-12; Lang, 2013, pp. 5-48; Strachota \& Falkowski, 2010, pp. 5-71). According to other estimates, by December 2015, up to 30,000 foreign fighters from 85 countries had joined the ranks of IS (Benmelech \& Klor, 2016, p. 1). At this point it is worth noting that Turkey alone apprehended over 90,000 people who illegally tried to cross the border with Syria (Szafarz, 2016, p. 51). What is more, according to United Nations estimates, there are still up to 30,000 Daesh fighters in Syria and Iraq (BBC News, 2018; Sly, 2018).

\section{Daesh against China}

Wojciech Grabowski recalls that with the official birth of the caliphate, a five-year expansion plan was announced, according to which ISIS was to cover the Middle East and Central Asia, the Balkans, part of Africa, the Iberian Peninsula, as well as areas in China, South-East Asia and Australia (Grabowski, 2016, p. 74). Still in 2014, Abu Bakr al-Baghdadi mentioned the Middle Kingdom as one of the goals of Jihad (Lin, 2014). Moreover, in propaganda films produced by al-Hayāt

\footnotetext{
${ }^{4}$ Daesh does not hide the fact that one of its main purposes is to destroy Western civilization as it is (Dabiq, 2017, pp. 30-33).
} 
Media Center (one of IS's propaganda agency), China is one of the members of the international coalition fighting Islam (al-Hayāt Media Center, 2015), what should have (in ISIS's view) encourage Muslims from all over the world to attack them. It is important to bear in mind, however, that Beijing has not actively participated in the fight against ISIS in Syria and Iraq5. On the other hand, it also has not protected its citizens from death at the hands of terrorists in front of television cameras in 2015. It should be borne in mind that at least some of them are most likely Uighurs who have fought previously in the ranks of the Islamic State and were executed for desertion (Tiezzi, 2015; van Nieuwenhuizen, 2015).

As already has been signaled at the beginning of this work, the threat posed by the IS to China is inextricably linked to Uighur separatism. Beijing's policy towards ethnic minorities, although in theory most conciliatory (Jarema, 2013b, pp. 49-55 $)^{6}$, in the case of the Muslim inhabitants of Xinjiang boils down to a broad spectrum of actions designed to lead in the long term to their complete assimilation. The basic tool in such a policy is demography - the Han Chinese make up about $90 \%$ of the 1.3 billion population of the Middle Kingdom, while the Uighurs is a group of about 10 million. The central government is carrying out a settlement campaign in Xinjiang, which within half a century has reduced the percentage of Uighurs from $3 / 4$ to less than half of the province's population. Not without significance for the demographic structure of the region is also the fact that, contrary to what Chinese decision-makers publicly proclaim, the "one-child policy" is being enforced against indigenous peoples with absolute ruthlessness. Numerous harassment is also directed against the Muslim religion (Adamczyk, 2016, pp. 17-19; see also: Bunin, 2018), which, as Tomasz Szyszlak stresses: "(...) undoubtedly permeates all spheres of life of the Uyghurs - political, social and economic, and the term 'Muslim' in Xinjiang refers not only to believers, but to all autochthons (...) in the case of Uighurs, the symbiosis of ethnic identity with religion is also clearly visible" (Szyszlak, 2012, p. 174). The answer from the Uighurs is to seek a state of their own, and the means are numerous terrorist attacks on Chinese territory - between 1990 and 2001 there were more than 200 acts of this kind, in which more than 160 people died and nearly 450 were injured (Jarema, 2013a, pp. 77-78). In the following years, bloody attacks also took place many times, e.g., in the summer of 2009, when clashes with the Chinese police

\footnotetext{
5 Although in mid-2018 there was another (and so far the last) wave of rumors about the participation of Chinese troops in the war in Syria (Pauley \& Marks, 2018; Stratfor, 2018), but they were quickly denied by Beijing (Zhou, 2018).

${ }^{6}$ It is worth recalling that minorities represent more than $8 \%$ of the population of PRC (Szyszlak, 2012, p. 167).
} 
took place in Xinjiang, nearly 200 people were killed and more than 1,600 injured (Szyszlak, 2012, p. 174). It is therefore no surprise that China has recognized the four largest Uyghur organizations as terrorist groups (Jarema, 2013a, pp. 76-77; Mikotajczyk, 2012, pp. 52-53). What is more, one of them, the Turkestan Islamic Party (TIP), is officially affiliated with the al-Qaeda (Hope, 2018). It seems that in retrospect it is difficult to objectively determine whose side is right in this conflict, and whether Chinese policy has led to radicalization of the region's inhabitants, or Islamic fundamentalism (until recently completely strange to Uighurs) has exacerbated Beijing's policy, which in turn has resulted in even greater radicalization of the autochthons. Undoubtedly, as has already been shown in earlier studies, China cannot afford to be anxious in Xinjiang, let alone the breakaway of the region - for political security reasons (this could lead to the secession of further provinces, e.g., Tibet), but also economic security reasons - huge coal, gas and oil reserves (Adamczyk, 2017, pp. 197, 201), also crucial Central Asia-China gas pipeline (Xie et al., 2018, p. 25; Hydrocarbons Technology, 2018), and of course military security reasons (as a "gateway to China" from the West and location of key nuclear installations - NTI, 2012), as well as an important starting point for further expansion in Central Asia or as an element of the "One Belt, One Road" project (Mikołajczyk, 2012, pp. 47-59; Trzaskowski, 2008, pp. 87-112). ISIS leaders, as well as the Uighurs themselves, are undoubtedly aware of the importance that the Chinese attach to this region - further attacks are likely to take place in Xinjiang itself, as well as in other Chinese provinces. Fighters experienced in the fighting in Syria and Iraq against coalition forces represent a particular threat in this perspective. At the other hand, Xinjiang is only a part of the Chinese problem with ISIS (and its potential successors), because while successive waves of repression against the Uighurs ${ }^{7}$ will finally break their resistance, it will be much more difficult for the Chinese to protect their assets abroad (in Africa or Middle East) or key transport routes, transmission lines, pipelines, etc.

In the above context, it is worth emphasizing that in 2015 IS released its first propaganda (recruitment) movie in Mandarin - followed by two more similar productions (Arirang News, 2015; Soliev, 2017). The next film contained threats against China from Uighurs fighting in Syria (Hope, 2018). Cautious estimates speak of more than a hundred Uighurs who joined the fight in the ranks of ISIS in the Syrian-Iraqi borderland. Other sources state that even several thousand figh-

7 What can Beijing afford in its own country without much conscience from the international community - who will take the side of the Muslim minority in times of high levels of Islamic terrorist threats? 
ters (up to 20,000) from Xinjiang are fighting in Syria in the ranks of the Islamic State, as well as within al-Nusra Front (since 2016 as the al-Qaeda in the Levant; Rosenblatt, 2016; Botobekov, 2016; Soliev, 2017; Hope, 2018) ${ }^{8}$. Even the Chinese Government does not deny that it could be even a few thousand fighters from Eastern Turkestan in Syria and Iraq (Blanchard, 2018). Some of them will return to China, some will dissolve in Africa or the Middle East, where there is no lack of potential Chinese targets to attack.

\section{Summary}

Although it is highly likely that in 2019 the Islamic State in Syria and Iraq will eventually cease to exist, it would be a truism to say that the threat posed by Islamic terrorism should not be underestimated. The author deliberately quoted the history of successive incarnations of the organization to show how flexible modern jihadist structures can be and how from almost complete annihilation they can - in a few years - move to the creation of a quasi-state entity in an area larger than the territory of Great Britain (al-Hayāt Media Center, 2015). Although China does not have to fear the creation of an Islamic caliphate on its territory in the near future, a large number of fighters who have joined the ranks of various terrorist organizations (like ISIS or al-Qaeda) may pose a threat to the internal stability of the state and its foreign interests. As shown above, Xinjiang is crucial for the PRC for a number of reasons, and Beijing's policy towards the Uyghurs living in the province is inextricably linked to the problem of Islamic terrorism in the country. Sooner or later, the central government will have to solve the problem of radicalizing Muslims, and a significant impediment will certainly be the influx of experienced and well-armed warriors, who had previously fought in the ranks of the caliphate. It should be borne in mind that ISIS also may still pose a threat to various Chinese investments in Africa and the Gulf region. It is obvious that China's key onshore and offshore oil and gas supply routes are exposed to an increased risk of terrorist attacks.

${ }^{8}$ It is worth remembering that already in 2016, the Uighurs connected with the Front made an attack on the Chinese embassy in Bishkek in Kyrgyzstan (Hope, 2018). 


\section{References:}

Adamczyk, M. (2016). Problem terroryzmu islamskiego w Chinach w kontekście dążeń niepodległościowych Ujgurów. In: M. Kopczewski \& D. Sienkiewicz (eds.). Edukacja warunkiem bezpieczeństwa $w$ XXI w. - Stużby mundurowe w systemie bezpieczeństwa publicznego (pp. 13-24). Koszalin: Wydawnictwo Centrum Szkolenia Sił Powietrznych.

Adamczyk, M. (2017). Analiza uzależnienia Chińskiej Republiki Ludowej od wybranych surowców energetycznych w kontekście chińskiej drogi do hegemonii. In: M. Górka (ed.). Globalne i lokalne problemy polityki bezpieczeństwa. Polska i świat. Vol. I (pp. 193-216). Poznań: Media-Expo.

Al-Hayāt Media Center (2015). The Islamic State - “And No Respite” (En). Retrieved from: https://videopress.com/v/mjRqgqAP.

Al-Jazeera. (2017). ISIL Expands in Afghan-Pakistan Areas, Widening Attacks. Retrieved from: https://www.aljazeera.com/news/2017/03/isil-expands-afghan-pakistan-areaswidening-attacks-170302041341156.html.

Ajili, H. (2016). ISIS and its Historical Origins. In: R. Ożarowski \& W. Grabowski (eds.). Arab and Muslim World in International Relations (pp. 38-62). Warsaw: Wydawnictwo Rambler.

Arirang News (2015). ISIS Using Song in Mandarin to Recruit Chinese. Retrieved from: https://www.youtube.com/watch?v=1fFm06V9FMw.

Azoulay, R. (2016). ISIS: Past, Present and Future. Przeglad Strategiczny, 9, 157-169. DOI: $10.14746 /$ ps.2016.1.12.

BBC News (2018). IS conflict: Up to 30,000 Fighters in Syria and Iraq - UN. Retrieved from: https://www.bbc.com/news/world-middle-east-45181501.

Benmelech, E., \& Klor, E.F. (2016). What Explains the Flow of Foreign Fighters to ISIS? NBER Working Paper, 22190, 1-25.

Blanchard, B. (2018). China Envoy Says No Accurate Figure on Uighurs Fighting in Syria. Retrieved from: https:/www.reuters.com/article/us-mideast-crisis-syria-china/chinaenvoy-says-no-accurate-figure-on-uighurs-fighting-in-syria-idUSKCN1L508G.

Botobekov, U. (2016). China's Nightmare: Xinjiang Jihadists Go Global. Retrieved from: hinas-nightmare-xinjiang-jihadists-go-global/.

Botobekov, U. (2017). Al-Qaeda and Islamic State Take Aim at China. Retrieved from: https://thediplomat.com/2017/03/al-qaeda-and-islamic-state-take-aim-at-china/.

Bunin, G.A. (2018). "We're a People Destroyed": Why Uighur Muslims across China Are Living in Fear. Retrieved from: https:/www.theguardian.com/news/2018/aug/07/whyuighur-muslims-across-china-are-living-in-fear.

Byman, D.L. (2018). What Happens When ISIS Goes Underground? Retrieved from: https:// www.brookings.edu/blog/markaz/2018/01/18/what-happens-when-isis-goes-underground/.

Chatterjee, R. (2018). ISIS Emerging Stronger as an Idea. Retrieved from: https://www. straitstimes.com/world/middle-east/isis-emerging-stronger-as-an-idea.

Dabiq (2017). Why We Hate You \& Why We Fight You. Dabiq, 15, 30-33.

Dubin, R. (2018). ISIS 2.0 Is Really Just the Original ISIS. Retrieved from: https://foreignpolicy.com/2018/04/03/isis-2-0-is-really-just-the-original-isis/. 
Durac, V. (2018). Islamic State: Defeated But Still Dangerous. Retrieved from: https:// www.irishtimes.com/news/world/middle-east/islamic-state-defeated-but-still-dangerous-1.3383585.

Dyner, A., Legieć, A., \& Rękawek, K. (2015). Ready to Go? ISIS and Its Presumed Expansion into Central Asia. PISM Policy Paper, 19(121), 1-16.

Dziennik.pl (2014). Dżihadyści zarabiaja fortunę na handlu narkotykami. Religia im tego nie zabrania. Retrieved from: https://wiadomosci.dziennik.pl/swiat/artykuly/473657,islamscy-terrorysci-handluja-kotykami-w-europie-pieniadze-trafiaja-na-dzihad.html.

Dzisiów-Szuszczykiewicz, A. (2011). „Arabska wiosna” - przyczyny, przebieg i prognozy. Bezpieczeństwo Narodowe, 2(18), 41-56.

Dzyubenko, O. (2016). Kyrgyzstan Says Uighur Militant Groups Behind Attack on China's Embassy. Retrieved from: https://www.reuters.com/article/us-kyrgyzstan-blast-chinaidUSKCN11C1DK.

Europol (2016). Changes in Modus Operandi of Islamic State (IS) Revisited. Retrieved from: https://www.europol.europa.eu/publications-documents/changes-in-modus-operandi-of-islamic-state-revisited.

Face the Nation (2017). Full Interview: Defense Secretary James Mattis, May 28. Retrieved from: https://www.youtube.com/watch?v=GR8TcsXcrMc.

Fijałkowski, Ł., \& Jarząbek, J. (2016). "Plague-Bearers”: Foreign Fighters in the Ranks of ISIS as a Threat for Theirs Home Countries. Selected Cases of Asian States. In: R. Ożarowski \& W. Grabowski (eds.). Arab and Muslim World in International Relations (pp. 63-80). Warsaw: Wydawnictwo Rambler.

Grabowski, W. (2016). Państwo Islamskie - aktor państwowy czy niepaństwowy? Roczniki Nauk Społecznych, 44(1), 69-86. DOI: http://dx.doi.org/10.18290/rns.2016.8(44).1-5.

Gramer, R. (2017). The Islamic State Pledged to Attack China Next. Here's Why. Retrieved from: https://foreignpolicy.com/2017/03/01/the-islamic-state-pledged-to-attack-china-next-heres-why/.

Hope, J. (2018). Returning Uighur Fighters and China's National Security Dilemma. China Brief, 18(13).

Hydrocarbons Technology (2018). Central Asia-China Gas Pipeline, Turkmenistan to China. Retrieved from: https://www.hydrocarbons-technology.com/projects/centralasiachinagasp/.

Jankowski, D. (2011). Po „arabskiej wiośnie” - „zima” dla europejskiej obrony? Bezpieczeństwo Narodowe, 2(18), 57-67.

Jarema, D. (2013a). Charakterystyka terroryzmu w Chińskiej Republice Ludowej. Zeszyty Naukowe Ruchu Studenckiego, 1, 72-80.

Jarema, D. (2013b). Polityka Chińskiej Republiki Ludowej wobec mniejszości etnicznych. Zeszyty Naukowe Ruchu Studenckiego, 2, 49-56.

Karczewski, M. (2015). Od Surge do państwa islamskiego. Przyczyny i uwarunkowania destabilizacji Iraku po 2011 roku. Przegląd Strategiczny, 8, 195-209. DOI: 10.14746/ ps.2015.1.14.

Kumelska, M. (2012). Zachodnie mocarstwa wobec wydarzeń w Afryce Północnej. Forum Politologiczne, 13(1), 391-408.

Lang, J. (2013). Zbrojni radykałowie islamscy z Azji Centralnej. Raport OSW, 11, 1-49. 
Lewis, J., \& Ali, A. (2014). The Islamic State of Iraq and al-Sham Captures Mosul and Advances toward Baghdad. Retrieved from: http://www.understandingwar.org/backgrounder/ islamic-state-iraq-and-al-sham-captures-mosul-and-advances-toward-baghdad.

Lin, C. (2014). Al Qaeda and ISIS Have Declared War on China - Will Beijing Now Arm the Kurds? Retrieved from: https://www.files.ethz.ch/isn/185086/299_Lin.pdf.

Machniak, A. (2016). „Państwo Islamskie” i jego wpływ na aktualne bezpieczeństwo międzynarodowe. Polityka i Społeczeństwo, 14(4), 126-140.

McCoy, T. (2014). Islamic State "Now Controls Resources and Territory Unmatched in History of Extremist Organizations". Retrieved from: https://www.washingtonpost.com/ news/morning-mix/wp/2014/08/04/Islamic-state-now-controls-resources-and-territory-unmatched-in-history-of-extremist-organizations/.

Mikołajczyk, S. (2012). „Dziki Zachód” Państwa Środka - bezpieczeństwo i gospodarka w chińskiej polityce wobec prowincji Xinjiang. Refleksje, 5, 47-59. DOI: 10.147 46/r.2012.5.3.

Münkler, H. (2004). Die neuen Kriege. Cracow: Wydawnictwo WAM.

NTI (2012). Lop Nor Nuclear Weapons Test Base. Retrieved from: https://www.nti.org/ learn/facilities/710/.

Pauley, L., \& Marks, J. (2018). Is China Increasing Its Military Presence in Syria? Retrieved from: https://thediplomat.com/2018/08/is-china-increasing-its-military-presence-insyria/.

Pasamonik, B. (2016). Fenomen europejskich dżihadystów. Multicultural Studies, 1(2), 13-30. DOI: 10.23734/mcs.2016.2.013.030.

Repetowicz, W. (2017a). Hatra: architektoniczny klejnot Mezopotamii odbity, kolejny celgranica Syrii [Relacja z Iraku] [Galeria]. Retrieved from: https://www.defence24.pl/ hatra-architektoniczny-klejnot-mezopotamii-odbity-kolejny-cel-granica-syrii-relacjaz-iraku-galeria.

Repetowicz, W. (2017b). Irak i Syria: Ogromne straty Państwa Islamskiego. Retrieved from: https://www.defence24.pl/irak-i-syria-ogromne-straty-panstwa-islamskiego.

Repetowicz, W. (2017c). Punkty zwrotne w wojnie z IS: Odcięcie drogi do Mosulu, uktad między Kurdami a Asadem [ANALIZA]. Retrieved from: https://www.defence24.pl/ punkty-zwrotne-w-wojnie-z-is-odciecie-drogi-do-mosulu-uklad-miedzy-kurdami-aasadem-analiza.

Roggio, B. (2008). Who is Abu Omar al Baghdadi? Retrieved from: http://www.longwarjournal.org/archives/2008/09/who_is_abu_omar_al_b.php.

Roman, Ł. (2016). Państwo Islamskie - zagrożenie dla pokoju i bezpieczeństwa. In: M. Sitek, G. Winogrodzki, \& Ł. Roman (eds.). Wspótczesne konteksty bezpieczeństwa (pp. 65-78). Józefów: Wydawnictwo Wyższej Szkoły Gospodarki Euroregionalnej im. Alcide De Gasperi w Józefowie.

Rosenblatt, N. (2016). All Jihad is Local: What ISIS' Files Tell Us about Its Fighters. Retrieved from: https://na-production.s3.amazonaws.com/documents/ISIS-Files.pdf.

RT (2017a). ISIS Advance: Libya Loses Control Over Oil Fields Amid Islamists' Sweeping Advance. Retrieved from: https://www.youtube.com/watch?v=EB_XX1oEKDo.

RT (2017b). ISIS Makes Military Gains in Philippines. Retrieved from: https://www.youtube.com/watch?v=AXsevF6U0Ng. 
RT (2017c). Libyan Sirte Becomes New ISIS Stronghold with Direct Sea Route to Europe. Retrieved from: https://www.youtube.com/watch?v=Tjykykyains\&feature=youtu.be.

RT (2017d). Philippines "At War”: Civilians Evacuated as Army Takes Fight to Terrorists in Marawi (EXCLUSIVE). Retrieved from: https://www.youtube.com/watch?v=9cx3M8c9P7E.

Sly, L. (2018). Islamic State May Still Have 30,000 Fighters in Iraq and Syria, Even After Setbacks. Retrieved from: https://www.washingtonpost.com/world/islamic-state-maystill-have-30000-fighters-in-iraq-and-syria-even-after-setbacks/2018/08/14/ f929cbe2-9fd6-11e8-a3dd-2a1991f075d5_story.html?noredirect=on\&utm _ term $=.37$ be $89867 \mathrm{~b} 41$.

Soliev, N. (2017). How Serious Is the Islamic State Threat to China? Retrieved from: https:// thediplomat.com/2017/03/how-serious-is-the-islamic-state-threat-to-china/.

Sputnik (2014). Narkotyk dla dżihadystów czy dla Europejczyków? Retrieved from: https:// pl.sputniknews.com/swiat/201706025591119-Francja-dihad-narkotyki/.

Strachota, K., \& Falkowski, M. (2010). Dżihad i nowa Wielka Gra. Paradoksy zagrożenia wojującym islamem w Azji Centralnej. Punkt Widzenia OSW, 1-73.

Surdyk, K. (2014). Terrorysta do wynajęcia - światowy dżihad w realizacji celów politycznych w Syrii. Zeszyty Analityczne IBnSM, 1, 1-74.

Stratfor (2018). China, Syria: Officials Say the Chinese Military Is Willing to Help the Syrian Army Retake Idlib. Retrieved from: https://worldview.stratfor.com/article/china-military-officials-help-syrian-army-retake-idlib.

Szafarz, A. (2016). Powstanie Państwa Islamskiego w Iraku i Wielkiej Syrii. Securo, 3, 45-53.

Szyszlak, T. (2012). Czynnik religijny w konfliktach etnicznych na przykładzie konfliktu chińsko-ujgurskiego. Zeszyty Naukowe Wyższej Szkoły Oficerskiej Wojsk Lądowych, 2(164), 167-181.

Tiezzi, S. (2015). ISIS: Chinese Hostage "Executed". Retrieved from: https://thediplomat. com/2015/11/isis-chinese-hostage-executed/.

Trzaskowski, P. (2008). Chińska strategia powrotu do Azji Centralnej - jedwabny szlak XXI wieku. Forum Politologiczne, 8, 87-116.

van Nieuwenhuizen, S. (2015). Is China About to Declare War Against ISIS? Retrieved from: https://nationalinterest.org/blog/the-buzz/china-about-declare-war-against-isis12201.

VICE News (2014a). Enforcing Sharia in Raqqa: The Islamic State (Part 3). Retrieved from: https://www.youtube.com/watch?v=jOaBNbdUbcA.

VICE News (2014b). Grooming Children for Jihad: The Islamic State (Part 2). Retrieved from: https://www.youtube.com/watch? v=jzCAPJDAnQA.

Waśko-Owsiejczuk, E. (2017). Wpływ polityki USA na powstanie „państwa” islamskiego. O spuściźnie prezydentury George’a W. Busha. Athenaeum. Polskie Studia Politologiczne, 53, 7-31. DOI: 10.15804/athena.2017.53.01.

Wojciechowski, S. (2016). Fenomen „Państwa Islamskiego” i jego źródła. Przegląd Strategiczny, 9, 143-155. DOI: 10.14746/ps.2016.1.11.

Worley, W. (2017). Who Are Isis in Afghanistan and Why Did Donald Trump Just Drop the "Mother of All Bombs" on Them? Retrieved from: https://www.independent.co.uk/news/ world/asia/moab-bomb-isis-in-afghanistan-why-did-us-use-gbu-43b-a7683241.html. 
Xie, L., Rui, X., Li, S., Fan, X., Shi, R., \& Li, G. (2018). A Critical Analysis on Influential Factors on Power Energy Resources in China. Modern Applied Science, 12(2), 1-35. DOI: $10.5539 /$ mas.v12n2p1.

Zhou, J. (2018). Beijing Denies Military Presence in Syria. Retrieved from: http://www. chinadaily.com.cn/a/201808/21/WS5b7b4ae1a310add14f386c96.html. 